Uşak Üniversitesi Sosyal Bilimler Dergisi

$2015,8 / 1$

\title{
Dijital Yaşamın Dijital Özne(1)leri: Herkes ya da Hiç Kimse
}

Özlem AVCI*

\section{Özet}

$\mathrm{Bu}$ çalışmanın konusu modern zamanlar içinde değişen yaşam koşullarımızın ve algılarımızın nasıl değiştiği temel teorik tartışmalar ekseninde yeninden düşünmektir. Özellikle modernizmle birlikte gittikçe güçlenen teknolojik gelişmelerle birlikte bireyin gündelik hayatının nasıl yeni bir biçime girerek dönüştüğü üzerinde durulacaktır. İletişim teknolojilerinin gelişmesi ve yeni kamusal yaşam alanlarının ortaya çıkması ile birlikte birey, gerçeklikle gerçek dışının iç içe geçtiği yeni alanlarda kendi var oluşunu ortaya koymaya çalışır. Özellikle internet teknolojisi ile karşımıza çıkan yeni medya alanları, niteliksel özelliklerimiz dışında bizi birbirimize benzeten ve kendimizi nicel olarak ifade ettiğimiz ve nicel olarak algılandığımız alanlara dönüşmüştür. Tüm iletişim teknolojileri içinde dijital olarak algılandığımız bu alanlar, hayata bakışımızı da dijitalleştirmekte, sayısallaştırmaktadır. Bu sayısallaşma beraberinde gözetimi de getirir. Böylece dijitalleşme ve gözetim en kolay iletişim teknolojilerinin gelişmesiyle internet üzerinden sürdürülür hale gelir. Bu ise yeni medyanın sunduğu sosyalleşme alanları olarak sosyal medya alanları üzerine yeniden düşünmeyi kaçınılmaz kılmaktadır.

Anahtar Kelimeler: Dijital Flanör, Sosyal Medya, Gözetle(n)me, Akışkan Modernizm.

\section{Digital Subjects of Digital Life: Everybody or Nobody}

\section{Abstract}

The subject of this study is that rethink onto the axis of the basic theoretical discussion about how is our everyday life and our perception changing in modern times. It is focused on how does everyday life of individuals transform into the new format with powerful technological development which is increased power by modernism? With development of communication technologies and emergence of new public spaces, the individual try to demonstrate its own existence in new places which is intertwined reality and imaginary. Especially, the new media areas are turned into the areas which make us very same and we express and perceive

\footnotetext{
*Yrd. Doç., Uşak Üniversitesi Fen Edebiyat Fakültesi Sosyoloji Bölümü
} 
ourselves as a quantitative. In all these technology of communication, these areas that perceived us as digitally, make our view to the life digitalization. This digitization also emerges surveillance. Thus, the digitalization and the surveillance become sustainable via internet. This is a necessity on rethinking about social media as a new socialisation fields.

Keys Words: Digital Flaneur, Social Media, Surveillance, Liquid Modernism.

\section{Dijital Yaşamın Dijital Özne(l)leri: Herkes ya da Hiç kimse}

Batı toplumlarnda, kapitalizmle birlikte, bireylerin davranışlarını, tavırlarını, bir şey yapma tarzlarını, bulunduklar yerleri, meskenlerini, yeteneklerini, sorumluluğu altına alacak, gözetleyecek, denetleyecek bir dizi prosedürün bir dizi tekniğin görüldüğ̈̈ kanısındayım.

Michel Foucault

İş bu vesileyle Velinimet adına, TekDevlet'in tüm Sayılarına duyurulur: "Yapabileceğine inanan herkesten, TekDevlet'in güzelliği ve yüceliğini vurgulayan tezler, epik şiirler, manifestolar, methiyeler ve diğer eserler hazırlamalar talep edilmektedir."

Yaşasın TekDevlet! Yaşasın Sayılar! Yaşasın Velinimet!

Yevgeni Zamyatin, "Biz"

\section{Giriş}

Toplumsal değişmenin en önemli itici güçlerinden olan teknolojiyle birlikte temel yaşam alanları ve ilişki biçimleri de hızlı bir biçimde değişime uğrar. Böylece toplumsal olana ve sosyalleşmeye yüklenen anlamlarda değişmeye başlar. Genel olarak toplum açısından başlica toplumsal anlam üretim kaynağı, toplumsallaşmış iletişim sürecidir. Toplumsallaşmış iletişim, kamusal alanda kişiler arası iletişimin ötesinde var olur. (Castells, 2008, s.4-5) Gelişen teknoloji ile karşımıza çıkan dijital alanlar, kişilerin kullanımına sunulmuş kişiler arası iletişimin ötesinde alanlardır. Bu alanlar kişileri bu alanlara çekerek, bir araya getirmekte ve böylece denetlenmesi, kontrol altında tutulması ve tüketim nesneleri haline gelmeleri kolaylaşmaktadır. Bu alanlarda sunulan yaşamlara uyum sağlamları ile 
birlikte beğeni ve istekleri oluşturulmakta ve manipüle edilmiş olarak tüketim döngüsü içine dahil olmaktadırlar.

$\mathrm{Bu}$ çalışmanın konusu ve amacı modern zamanlar içinde değişen yaşam koşullarımızın ve algılarımızın hangi koşullar altında ve nasıl değiştiğinin ana çizgisini oluşturmak ve bu konudaki teorik tartışmaları yeniden düşünmeye başlamaktır. Özellikle modernizmle birlikte gittikçe güçlenen teknolojik gelişmelerle birlikte bireyin gündelik hayatının nasıl yeni bir biçime girerek dönüştüğü üzerinde durulacaktır. İletişim teknolojilerinin gelişmesi ve yeni kamusal yaşam alanlarının ortaya çıması ile birlikte birey, gerçeklikle gerçek dışının iç içe geçtiği yeni alanlarda kendi var oluşunu ortaya koymaya çalışır. Özellikle internet teknolojisi ile karşımıza çıkan yeni medya alanları, niteliksel özelliklerimiz dışında bizi birbirimize benzeten ve kendimizi nicel olarak ifade ettiğimiz ve nicel olarak algılandığımız alanlara dönüşmüştür. Tüm iletişim teknolojileri içinde dijital olarak algılandığımız bu alanlar, hayata bakışımızı da dijitalleştirmekte, sayısallaştırmaktadır. Böylece içinde yaşadığımız tek toplumsal alanımız, dijital olarak işleyen sosyal medya alanları haline gelmeye başlar. Klasik sosyoloji teorileri içinde tartıştı̆̆ımız modern toplumlarda bireyselleşmenin gittikçe artması ve topluluk bilincinin azalması anlayışı, iletişim ve internet teknolojilerinin gelişmesiyle birlikte farkı bir boyut kazanmaktadır.

Diğer yandan yeni medya teknolojileri ile özellikle de sanal medya ile kur(g)ulanan yaşam biçimleri üzerinde düşünmek de dikkate değerdir. Herkesin birbirini gözetlediği ama hiç kimsenin birbirini görmediği bir toplum ne kadar yaşanılabilir ve ne kadar mümkündür? sorusundan hareketle bireyin yeni sosyalleşme alanlarını nasıl kullandıkları betimlenerek, anlaşılmaya ve açıklanmaya çalışılacaktır. Ayrıca toplumsal alanda böylesine bir gözetlemeye ve gözetlenmeye neden ihtiyaç duyulmaktadır?

Sayısallaşmayı ve gözetlenmeyi bir arada düşündüğümüzde ise sayılabilen daha kolay denetlenmekte, kontrol altına alınabilmektedir. Bilgi toplayan ve sunan bu alanlar, iktidar için önemli bir araç haline gelmektedir. Foucault'un da söylediği gibi bilgi ve iktidar arasında doğrudan bir bağlantı vardır. İktidar bilgiye ihtiyaç duyar ve bu bilgiyi elde etmenin tüm yollarını dener. Çünkü bilgi iktidarın gücünü sağlayan ve devam etmesini sağlayan önemli bir unsurudur. Yeni iletişim teknolojileri sayesinde iktidar bilgiye daha kolay ve çabuk ulaşabilmekte ve böylece denetim ve kontrolü daha etkili bir biçimde sağlayabilmektedir. Tüm bu nedenlerden dolayı dijitalleşme ve gözetim hem birinin nedeni hem de sonucu olan iki unsur olarak karşımızdadır. 


\section{Modern Zamanların Getirdikleri: Dijital Yaşamlar ve Gözetim Toplumu}

Burada "dijital"1 ve "gözetim" kavramı birbirleriyle olan ilişkisel bağlarıyla birlikte açıklanacaktır. Çünkü denetim toplumlarında bireyler sayısal kodlanmakta ve böylece denetimleri daha da kolaylaşmaktadır. Verilerin toplandığ 1 ve kodlandığı ve bunun üzerinden daha kolay bir kontrol ve denetimin sağlandığı alan ise yine bir sayı üzerine kurulmuş bir istem olan bilgisayar sistemiyle ${ }^{2}$ oluşturulmuş sanal alanlardır. Sayısal olarak ifade edildiğimiz ${ }^{3}$ ve ölçüldüğümüz bir dünyada dijital yaşamların ${ }^{4}$ sürdürülmesi oldukça olağan görünen bir durum olarak karşımızdadır.

Modernleşme süreci ile eş zamanlı olarak gelişme gösteren teknolojik ilerlemenin bir aşaması da internet teknolojilerinin ortaya çıkışıdır. John Ryan ’a göre sanayi devrimi ile başlayan teknolojik ilerlemede,

${ }^{1}$ Fransızca ve İngilizce kökenli olan digital sözcügü "tamsayılara ilişkin, sayısal" sözcügüünden alıntıdır. Fransızca sözcük İngilizce digit "1 ile 10 arası sayıların her biri, rakam" sözcügünden türetilmiştir. Bu sözcük Latince digitus "parmak, özellikle işaret parmağı" sözcüğünden alıntıdır. Latince sözcük Hint Avrupa Anadilinde yazılı örneği bulunmayan *dik- biçiminden evrilmiştir. Bu biçim Hint Avrupa Anadilinde yazılı örneği bulunmayan *deik- "işaret etmek, belirtmek, göstermek" kökünden türetilmiştir. www.nisanyansozluk.com (25.06.2014) Türk Dil Kurumu Sözlügü ’ün "verilerin bir ekran üzerinden elektronik olarak gösterilmesi, sayısal olan" olarak tanımladığı dijital sözcüğ̈̈, yeni medya sosyolojisi açısından ele aldığımızda, bireylerin ekranlarda sayısal olarak ifade edilmesi olarak tanımlanması yanlış olmayacaktır.

${ }^{2}$ Bilgisayar program sistemi 0 ve 1 sayılarından oluşan bir komut sistemidir. Yani sayısal ve sayısallaştıran, dijital bir sisteme sahiptir.

3 "100 milyon avro gol attı"... Ercan Taner' in 24 Mayıs 2014 Real Madrid - Atletico Madrid maçında, Gareth Bale`in golünden sonra kullandığı cümle. Bu makale üzerine çalışırken, konuyla ilgili karşılaştı̆̆ım en ilginç örneklerden birisi de bir futbol maçı sırasından spikerin gol atan bir oyuncuyu adıyla değil, transfer edildiği ücretle tanımlaması, çalışmanın konusu açısından oldukça dikkat çekici bir örnek olarak verilebilir.

${ }^{4}$ Dijital bir yaşamın tarifi olarak bir blog sayfasında yapılan şu betimleme oldukça ilginçtir: "Sabah uyandım, tabletteki şirinler oyunumda ekinlerim çıkmıştı onları biçtim, 8 saatlik başka bir şeyler ektim, ek puan getiren oyunlarını oynadım, telefondan maillere baktım gece ben uyuduktan sonra ne gelmiş diye, instagram, twitter, facebook ve foursquare kontrol ettim, duş aldım, bilgisayar başına geçtim, akşama kadar çalıştım, akşam playstation'ı update ettim, merak ettiğim iki oyunun trailerlarını download ettim, televizyonu update ettim, yeni uygulamaları, oyunları kurdum, şirinlerde ekinlerim çıktı onları biçtim, yenilerini ektim (sabaha çıkacaklar), tv, tablet, bilgisayar ve telefon üzerindeki bütün medya dosyalarına izin veren uygulamayı kurup test ettim (imedia share), tablete tv'nin orjinal kumandasını kurdum (pek işe yararmış, kumandanın ışığı olmadığından tuşları bulmakta zorlanıyordum). Yatmadan önce şirinlerin oyunlarını oynayıp ek puan getiren şeyleri deneyeceğim. Yarın evin ses sistemi için bulduğum kablosuz bir çözüm var onu tr de satan varsa sipariş edeceğim. Umarım tabletle uyumlu bir uygulamasını bulurum. Kimine göre üzücü, bana göre eğlenceli, geliştiriciler için ios hariç bütün platformlar var. Güzel... Normal hayata dönersek: fasulye pişirdim geçenlerde çok güzel oldu, pilav konusunda teflon tencereyle kesin çözüm, bir ara parmesanlı biftek deneyeceğim." http://blog.artuc.net/dijital-yasamlar/ (03.04.2014) 
buhar gücünün kullanımı, telgraf, endüstrileşen ticaret ve savaşlar dünyanın temposunu hızlandırmıştır. Dijital çağın getirdiği değişim endüstri devriminin yarattığı kontrol ve hiyerarşiye dayalı merkezileşmiş dünya düzeninin de merkezi noktaları ortadan kalkarak, ağ ve şebekeler boyunca uzanmış çok sayıda noktanın var olduğu bir yapıyı getirmiş olmasıdır. Politik ve kültürel yaşam da bu ağ yapısına göre yeniden yapılanmaktadır (Ryan, 2010, akt. Başlar).

Bilgisayar ve internet kullanımının hızla arttı̆g 1 şu dönemlerde, gelişen iletişim teknolojisi bireylerin sosyalleşme alanlarını yeniden tanımlamaktadır. Sosyal medya ajansı "We are Social" tarafından hazırlanan "2014 Sosyal Medya ve İnternet Kullanım İstatistikleri"ne göre toplam nüfusu 80 milyon olan Türkiye`de, nüfusun \% 45 `i internet kullanmaktadır. Yaklaşık 35 milyon insan aktif olarak internet kullanmakta ve bu 36 milyon (sahte hesaplar da dahil) kullanıcının aktif facebook hesabı var. Günde ortalama 4.9 saatimizi bilgisayar üzerinden, 1.9 saatimizi ise mobil telefonlar üzerinden internette ve 2 saat 32 dakikamızı ise sosyal medya alanlarında geçiriyoruz. Türkiye de en fazla kullanıcısı olan sosyal medya alanları ise Facebook (\%93), Twitter (\%72), Google+ (\%70) ve LinkedIn (\%33). (2014 Global Digital Statistics) İnternetin böylesine yoğun bir kullanımı, bireylerin internet çevresinde bir yaşam yeni bir yaşam alanı oluşturduklarının önemli bir göstergesidir. Özellikle sosyal medyanın böylesine yoğun bir kullanımı bu iddiayı doğrular niteliktedir. Bu verilerin ortalama veriler olduğunu düşünürsek, internete sahip olmayan ve ulaşamayan nüfusu da düşündüğümüzde internet kullanma imkanına sahip olanların kullanım sıklığı ve oranının oldukça yüksek olduğu söylenebilir. Gündelik yaşam içindeki tüm ihtiyaçlarını internet üzerinden karşılayan bireyler (alışveriş, oyun, sohbet, eğlence, çalışma vs gibi), bu araç etrafında kendilerini kapatmaktadırlar. Bu araçla yaşamlarını sürdüren ve yönlendiren bireyler, sürekli kayıt altında hareket etmekte ve sayısal olarak denetlenmektedirler: Alışveriş yaptığı yerler, ne aldığı, nereden aldığı, kimlerle görüştüğü, ne hakkında görüştüğü kayıt altına alınmakta ve tüm bunları yaparken de tüm kişisel bilgilerini paylaşmaktadır. Böylesine tüm kişisel bilgilerin kayıt edildiği ve paylaşıldığı bir veri tabanına dahil olmak Bauman’a göre eğlenceye giriş biletini almış olmakla aynı anlama gelmektedir. Bireyler artık “kredi verilmeye değerdir" (Bauman, 2006, s.61).

Böylesine bir alana, gönüllü olarak kapanan bireylerin hem üretim güçleri - tüketime yönlendirmek anlamında - hem de iktidar tarafından güvenlik adına - kontrolü ve denetlenmesi kolaylaşmaktadır. Böylece bireylerin kayıtlı tüm bilgileri hem üretici için hem de iktidar için kolay ulaşılabilir ve kontrol edilebilir hale gelmiştir. Dolayısıyla bu alanların 
dijitalleşme ve gözetleme üzerinden yeniden okunması ve tartışılması kaçınılmaz olmaktadır. "Nasıl ve neden sayısallaşıyoruz/dijitalleşiyoruz?" ve "Nasıl gözetleniyoruz?" Bu tartışmaları ve sorgulamaları yaparken elbette hareket noktası olarak birey ve toplum ikiliğinden hareket etmek anlamlıdır: Değişen toplum yapısının birey üzerine etkileri ve etkilenen bireyin içinde bulunduğu toplum yapısını yeniden biçimlendirme etkisi üzerinde tartışmak çift yönlü ele almak gerekir.

Denetim toplumlarında yurttaşları kodlama, şifreleme ve sayısallaştırma oldukça önemli bir role sahiptir. Tıpkı Zamyatin'in "Biz" (Zamyatin, 2010) romanında olduğu gibi, e-devlette de yurttaşların sayılardan ve kodlardan ibaret olduğu görülmektedir. Yurttaş olmak, artık, veri tabanına dahil olmak ve aynı zamanda bir sayı olarak var olmak anlamına gelmektedir. Devlet, bireyleri kayıt altına almak için çaba sarf etmemekte, bireyler sistem içerisinde var olabilmek için kendilerinin gönüllü olarak kayıt altına alınması istemektedir. Bunu da güvenlik adına gerçekleştirmektedir (Toktaş, Binark, Dikmen, Fidaner, Kuzeci, Özaygen, 2012, s.38).

İnternet teknolojisinin gelişimi ile ortaya çıkan yeni sosyalleşme alanları toplumsal olana ve toplumsal ilişkilere yeni anlamlar yüklemektedir. Artık toplumsallaşma alanları ve süreçleri, gelişen bu internet alanlarına ya da sosyal medya alanlarında yeni anlamlara sahip olmakta ve yeni değerler yüklenmektedir. Ortaya çıkan bu alanlar, kendi aralarında ağlar oluşturarak güçlenmekte ve gelişmektedir. Bu durumu ağ toplumu olarak ifade eden Manuel Castells'e göre enformasyonu ön plana çıkaran ağ toplumu bilişim teknolojileri tarafından harekete geçirilen, bilişim ağlarında oluşan ve tüm küreye yayılmış yeni bir toplumsal organizasyon yapısıdır. Bu yapı insanlar arasında kültür aracılığıyla şekillenen bir etkileşim ortaya koyduğu gibi; üretim, tüketim ve güç ilişkilerini de etkilemiştir. (Castels, 2005, 127) Bu bilgi ve iletişim teknolojileri ağlar aracıllğıyla, toplumsal alanla yeni gruplar, topluluklar oluşturmaktadır. Böylece gittikçe parçalı bir toplum yapısı ortaya çıkmaktadır. Aynı parçalı yapı, ağ yapıları içinde de karşımıza çıkmaktadır ve benzer bir biçimde sayısallaşma ve gözetim, burada da devam etmektedir. Çünkü parçalı bir yapının sayısal olarak kontrolü ve denetimi, toplumun bütününe göre daha kolaydır.

Çalışmalarında "modern yaşam ve birey üzerindeki etkilerini" tartışan Antony Giddens, sayısallaşma ve gözetimi modernitenin bir sonucu olarak ele almıştır. Modernizm içinde gözetim ve gözetlemenin iki farklı anlamına değinir: İlki, gözetim şifrelenmiş bilgi birikimidir. Burada kişilerin nesneler haline getirilerek kodlanmasından, sayılmasından bahseder. 
Toplanan bilgiler, sadece basit bir bilgi toplama işlemi değildir; toplanan bu bilgiler belli bir sınıflama ve ayırt etme işlemi de içerdiği için nitelikli bir bilgi depolama işlemidir (Giddens, 2008, s.24). Bu bilgi toplama ve depolama işlemi, neo-liberal toplumlar için tüketici taleplerinin oluşturulması / üretilmesi açısından oldukça önemlidir. Kişinim sahip olduğu özellikler, tüketici olarak bireyin yeni ürünlere ihtiyaç duyarak ona yönelmesi için daha kolay manipüle edilmekte, ihtiyacı olmayan ihtiyaçları oluşturulmaktadır. Ve böylece tüketim döngüsü hiç durmadan devam edebilmektedir. Dolayısıyla tüketim toplumu içinde bireylerin gittikçe "nesne"leştiği bir durum söz konusudur. Gözetlemenin ikinci anlamı ise, iktidarın bireyleri izlemesi, kontrol etmesi ve kolayca denetleyebilmesidir. Modern toplumlarda, kişilerin hareketleri sınırları daha belirgin alanlar (fabrika, büro, hapishane, akıl hastaneleri ${ }^{5}$ ) içinde gerçeklemektedir. Böylelikle, toplumsal yaşama egemen gruplar diğerlerinin hareketlerini daha etkin bir şekilde izleme ve denetleme yetisine sahiptirler. Çünkü sınırları belli bir mekan olmaları onları daha kolay kontrol etme imkanı sağlamaktadır. Giddens`a göre modern zamanların bir gücü olan gözetleme, "yönetim iktidarı" olarak modern devlette daha fazla önem kazanmıştır ve devletin "idari kapsamını" yönetmesine denk gelir (Giddens, 2008, s.71). İktidar bu gözetleme işini "güvenlikli bir toplum" yaratma gerekçesiyle sürdürmekte ve bunu gelişen yeni iletişim teknolojileri sayesinde daha da kolay gerçekleştirmektedir.

Her şeyin sayısal olarak ölçüldüğü ve değerlendirildiği içinde yaşadığımız dünya, modernleşme süreci içinde gelişen teknolojinin kaçınılmaz bir sonucu olarak karşımızdadır. Birey, modernleşme içinde olmanın verdiği dayanılmaz hafiflikle muazzam bir güç elde ederken, diğer yandan toplumsal alanda farkında olmadan bir takım olumsuz unsurlarla da kuşatılmaktadır. İletişim teknolojilerinin insana sağladığı olanaklarla kendini daha özgür hisseden birey, aslında güvenlikli bir toplum yaratma gerekçesiyle daha çok denetlenmekte, kontrol altına alınmakta ve özgürlüğü gittikçe kısıtlanmaktadır. Dolayısıyla birey, yanlış bir bilinçlilik halini içindedir. Bilgisayar, cep telefonu, internet gibi teknolojiler gündelik yaşamı bir yandan kolaylaştırırken öte yandan da insanların gündelik yaşamlarını gözetim altında tutmaktadır. Alışveriş sırasında kredi kartı kullanımından,

${ }^{5}$ Modern zamanların bu mekanlarına Foucault "disipline edici mekanlar", Goffman "total kurumlar", Weber ise "demir kafes" adını vermiştir. Dolayısıyla bu mekanlar üzerinden bireyin kontrol edilmesi, denetlenmesi bireyleri aynılaştırmakta, disipline etmekte ve bir kafes misali daha kolay kontrol etmektedir. 
sağlık bilgilerinin kayıtlanmasına, telefon ve internet kullanımına değin birçok gündelik yaşam etkinliği gerçekleştirildiğinde, bireyler geniş bir veri tabanına dahil edilmektedir. Böylelikle gündelik yaşam pratikleri kontrol altına alınmakta ya da suç olarak nitelendirilebilecek davranışlara zemin yaratmayacak şekilde düzenlenmiş olmaktadır. Dolayısıyla "suçtan arınmış bir toplum ütopyası"nı (Özkazanç, 2007, s.15) olanaklı kılacak böyle bir düzenlenmenin gerçekleştirilmesi adına yurttaşların sıradan bilgileri ve hatta özel bilgileri dahi devletin ve özel şirketlerin elinde toplanmaktadır (Toptaş vd, 2012, s.17). Bu noktada Marshall Berman'ın modern olmak üzerine şu ifadesi oldukça açıklayıcı olacaktır:

Bugün dünyanın her yanında insanların paylaştığı bir yaşamsal deneyim tarzı vardır. Bu deneyimin tamamına modernlik olarak adlandirmak istiyorum. Modern olmak, bizlere, serüven, güç, coşku, gelişme, kendimizi ve dünyayı dönüştürme olanaklar vadeden; ama bir yandan da sahip olduğumuz her şeyi, bildiğimiz her şeyi yok etmekle tehdit eden bir ortamda bulmaktır kendimizi. Modern ortamlar ve deneyimler coğrafi ve etnik, sinıfsal ve ulusal, dinsel ve ideolojik sinırlarm ötesine geçer; modernliğin, bu anlamda insanlığı birleştirdiğgi söylenebilir. Ama bu çelişkilerle dolu bir birliktir, bölünmüşlüğ̈̈n bir birliğidir: Bizleri sürekli parçalanma ve yenilenmenin, mücadele ve çelişkinin belirsizlik ve acının girdabına sürükler (Berman, 2004, s.27).

Dolayısıyla modernizm gelip geçiciliğin, hızlı bir değişimin yaşamsal deneyimlerini de dönüştürerek toplumsal yapı içinde görülen farklılaşmalar ve parçalanmalara işaret eder. "Katı olan her şey buharlaşıyor, kutsal olan da dünyevileşiyor" diyen Marx`a göre kapitalizmle birlikte her şeyi maddi unsura dönüştüren bu modernleşme süreci, en kutsal olan insanı da maddileştirmekte, sayısal bir değer vermekte ve buharlaştırmaktadır. Elbette bunun yaparken bir taraftan da Berman'ın söylediği gibi güç vadetmektedir. Maddileşen her şey sıvı hale gelmekte yani akışkan bir biçime bürünmekte ve bu akışkanlık yok olma ya da görünmez olma noktasında buharlaşmaktadır. Her şeyi maddeye dönüştüren ve sayılarla tanımlayan bu süreç, maddenin akışkanlığı ile birlikte artık her yere sızmakta ve içine sızdığı nesnenin ve mekanının biçimini almaktadır. Yani modernleşen dünyada akışkan hale gelen birey kendi varlığının dışında ait olduğu alanın biçimine bürünür. Bu yeni alanlarda yeni imkanlar ortaya koyarken aslında kendi varlığını ve öznelliğini yitirmeye başlar. 
Modernizmin karşımıza çıkardığı bu hızlı değişimi Bauman "akışkanlık" olarak tanımlamaktadır. ${ }^{6}$ Bauman ve Lyon’a göre sosyal medyanın varlığı, kullanıcıların izlenmesine ve edinilen bilgilerin diğerlerine satılmasına bağlıdır. Sosyal medyanın direniş için sunduğu olanaklar çekici ve bazı açılardan yararlı olabilir, fakat gittikçe akıcılaşan bir dünyada kalıcı ilişkiler kurabilmek için gerekli koşulların olmaması ve sosyal medya içerisindeki gözetim gücünün yerleşik ve etkili olması nedeniyle aynı zamanda kısıtlıdır (Bauman ve Lyon, 2013). Sosyal medyanın sunduğu bu akışkan yapıyla, denetim ve kontrolü güçlendirirken, toplumsal bağları zayıflatan, her şeyin çok çabuk tüketildiği ve gelip geçiciliğin esas olduğu bir toplumsal alan ortaya çıkmaktadır.

\section{Akıșkan ve Kaygan Bir Alan: Sosyal Medya}

Anthony Mayfield, sosyal medya türlerini sosyal ağlar, bloglar, wikiler, podcastler, forumlar, içerik toplulukları ve mikrobloglar olmak üzere 6'ya ayırmaktadır. Sosyal ağlar insanların kişisel web siteleri kurarak, arkadaşlarıyla iletişim kurmalarına ve içerik paylaşmalarına olanak sağlamaktadır. Facebook, MySpace, Wikipedia, Apple iTunes, YouTube, Twitter gibi internet siteleri sosyal ağlara örnek olarak gösterilebilmektedir. Mayfield'e göre sosyal medya insan olma özellikleriyle yakından ilişkilidir. Yazar sosyal medyayı düşünceleri paylaşmak, bir araya gelmek, ticaret yapmak, arkadaşlar aramak, tartışmalar yapmak gibi insani özelliklerin internete yansıması olarak görmekte ve çok hızlı bir şekilde yayılmasını da bu özelliğine bağlamaktadır. Teknolojilerin gelişmesiyle, dijital kameraların, fotoğraf makinelerinin ucuzlaması, hızlı internet erişiminin artması gibi bu alandaki maliyetlerin azalması ve kullanımın basitleştirilmesiyle insanlar kendi fotoğraflarından, videolarından, düşüncelerinden, sözlerinden kendi içeriklerini oluşturarak bunları yayabilme şansı elde etmiştir (Mayfield, 2008, akt. Başlar).

Çă̆daş sanatın en önemli temsilcilerinden olan Andy Warhol`ın "herkes bir gün on dakikalığına ünlü olacak" iddiasına referans vererek, biz her gün çektiğimiz videolar ve fotoğraflarla ünlü oluyoruz, tanınıyoruz, yüzlerce kez beğeniliyoruz, yüzlerce kez beğeniyoruz, binlerce takipçimiz var, bizde takip ediyoruz, onlarca fotoğrafımızı paylaşıyoruz (hatta en özel olanları bile), yüzlerce arkadaşımız var.

${ }^{6}$ Burada Bauman’ın "akışkanlık" kavramına daha ayrıntılı olarak şu kitaplarından bakılabilir: Liquide Modernity (Polity, 2000), Liquide Times (Polity, 2006) Akışkan Aşk (Versus, 2011), Akışkan Gözetim (Ayrıntı, 2013). 
Bireysel farklılıkların kaybolduğu bu yeni toplumsal alanlarda belirginleşen gözetim, zaman ve mekan mefhumunu aşarak akışkan bir biçimde zihinlere ve yaşamlara sızarak benzeştirmektedir. Yeni medya ve bu akışkan ilişkiler, karşılıklı olarak birbirlerini var etmekte ve sürekli olarak dönüştürmektedir. Yeni medya bir yandan toplumsal ilişkileri parçalamakta ama bir yandan yeni gruplar (kamplar) oluşturarak mahremiyetin kaybolduğu yeni yaşam alanları yaratmaktadır.

Bauman ‘n mahremiyetin yok oluşu olarak tanımladığı sanal dünya ve internet teknolojisi her şeyi gören/görüntüleyen ama görünmez olan bir alan olarak karşımızdadır:

Mahrem olan her şey artık potansiyel olarak kamusal alanda yapilıyor ve kamunun tüketimine açık halde; sayısız sunuculardan herhangi birinde kayitl olan herhangi bir şeyi internete 'unutturmak mümkün olmadığı' için sonsuza değin de ulaşılabilir kalacak (Bauman ve Lyon, 2013).

Mahremiyet kavramının en çok sorgulandığı bir sosyal medya alanı olarak Facebook, kavramın biçim ve içeriğini kökten değiştirmiş ve yeni algılarla yeniden tanımlamıştır. Facebook un kullanımı üzerine "Toplumsal Paylaşım Ağı Facebook: "Görülüyorum Öyleyse Varım!" adlı çalışmada;

Facebook kullananlarm mahrem algisinın değişmesi, kamusal alanda gözetim ve denetimi nasıl kavrayarak, uyum sağladıkları ile, Facebook vb. toplumsal paylaşım ağlarında gelişen iki yeni olgu: teşhircilik ve muhbircilik. Bu iki olgu, yeni medyanın gündelik yaşam rutini içerisindeki önemli rolünün de yansılarıdır, denilebilir. Yeni medya döneminde dolaşıma sokulan popüler kültür anlatılarında bireye haz veren artık görüntünün egemenliğidir. Görsel olanın egemenliği, beri yandan da sürekli görmeyi ve görülmeyi de doğal ve meşru hale getirmekte, bu iki edimin de birey tarafından kanıksanmasım sağlamaktadır. Görmek isteyen birey mikro iktidar düzleminde toplumsal paylaşım ağlarında eski velveya yeni arkadaşlarm gözetlemekte, makro iktidar düzleminde ise bu bireyin sanal uzamda biraktığg tüm elektronik ayak izleri başta ulus-devletin emniyet güçleri olmak üzere tüm kapitalist örgütlenmeler tarafindan da takip edilmektedir. Toplumsal paylaşım ağlarında tıklanan reklamlar, ziyaret edilen arkadaş hesaplar sürekli ve düzenli olarak reklamcillk ve pazarlama şirketleri tarafindan ayrintıli olarak kayıtlanmakta ve kişiselleş(tiril)miş reklam kampanyası veya ürün tanıtımı için bu veri bankası kullanılmaktadır... Üstelik Facebook ve Twitter toplumsal ilişkilerimizi kurma ve devam ettirmenin giderek daha fazla temel alanı haline geldikçe, bu alanlarm mikro ve makro iktidar yapılar tarafindan düzenlenmesi ve yönetilmesi konusundaki özen de artmaktadır (Toprak vd, 2009). 
Aynı çalışmada gözetlenmenin ve sayısal olarak kayıt altına alınmanın bireyin yaşamına nasıl dahil olduğu ve iktidarın bunu nasıl kontrol ettiği tam da Foucaultcu anlamda şu şekilde açıklamaktadırlar:

Hemen her köşe başına konulan kameralardan edinilen görüntü kayıtlarl, cep telefonlarının yaydığı sinyaller, bilgisayar IP numaraları, e-posta takip sistemleri, ilerisi, uzaya firlatılan uydular aracilığılla tüm dünya gözetim altında tutulmaktadır. Birkaç yıl öncesinde piyasaya sürülen GoogleEarth programı ile evinde, oturduğu yerde tüm dünyayı gözetleme olanağına erişebilen "stradan" bireyler için iktidarın ne denli kapsaml sistemlere sahip olduğunu düşünmek ürkütücüdür. Bugün teknolojinin ulaştığ $b u$ korkunç nokta ile, bireyin gözetlenmekten korunma olanağ yoktur. Cep telefonu, bilgisayar gibi görece daha yeni ve pahalı ürünler bir yana, televizyon ve hatta radyo dâhil hiçbir teknolojik ürüne sahip olmayan, dahası evinden dişarı adım atmayan bireyler dahi bu enternasyonal gözetim ă̆ına yakalanmışlardır (Toprak vd, 2009, s.146-147).

Böylesine iletişim teknolojisi üzerinden her yeri kuşatan iktidar, mekan üzerinden tahakkümünü yeniden tanımlamakta ve yeni tahakküm alanları oluşturmaktadır. Bireylerin gönüllü olarak dahil oldukları bu yeni alanlarda, daha kolay kontrol edilmekte ve sayısal olarak takip edilebilmektedir.

\section{Gözetlemenin Simetriği: Gözetleyen ve Gözetlenen Dijital Flanör}

Yeni iletişim, gerçekte yeni kapitalizmin işleyişinin temel belirleyenlerindendir ve öznenin yeni iletişim ortamları üzerinden yenidenüretimi daha kolaydır ve tüketimin yoğunlaşması bakımından da daha fazla avantaj içermektedir. İnternet ve tarayıcılarla birlikte, amaç satıcılara ekonomik olarak uygun tüketicileri oluşturan bireyleri belirlemek için gerekli enformasyonu sağlamaktır" (Campell, 2002, s.587, akt. Barış Çoban).

Kapitalizm özneyi hem üretim sürecinde hem de tüketim sürecinde yeniden üretirken, bu süreçlerde öznenin zevk ve gönüllükle katılımını sağlayacak bir "imgeler dünyası" yaratır, bu "sanal dünya" gerçeklikte öznenin yaşayamadıklarını yaşamasına olanak sağlayan bir yanılsamalar dünyasıdır. Öznenin hem kendisini kişisel anlamda yanılsamalı da olsa bir bütünlük olarak kurgulayabildiği bu dünya yeni iletişim teknolojileri ile birlikte gözlemlenebilir hale gelmiştir. Geçmişte "haz ekonomisi" olarak adlandırılabilecek eğlenceye dayanan bir kültür endüstrisinin ürünleriyle, yani filmlerle, tiyatrolarla, farklı gösteriler, konserlerle, tüketimci karnavallarla kendi öznelliğini özgürce yaşadığı sanrısında olan özne şimdi yeni iletişim teknolojileri üzerinden kendisini var etmeye çalışmaktadır. Bu yeni süreç hem de tüketimsel hem de takip edilebilir bir hal almıştır. 
Öznenin üretim sürecinde gözetlenmesinin yanında artık etkin bir biçimde tüketim sürecinde de gözetlenmesi ve bu sürecin kaydedilip, değerlendirilmesi söz konusudur. Öznenin gündelik yaşamındaki etkinlikleri gözetlenip denetlenebilir, buna bağlı olarak da yönlendirilebilir bir biçim almıştır. Yeni teknolojilere dayanan tüketim ve gözetim toplumunda birey kendisine bir "imaj" edinmekte ve buna uygun bir kültürel ortam içerisinde yaşamaktadır. Kapitalizmin ürettiği "imajları tüketerek kedisine sahte bir imaj yaratmakta ve kendi varoluşunu nerdeyse tamamen kapitalizme gönüllü olarak teslim etmektedir (Çoban, 2009).

Günümüz dünyasının panoptik-sonrası olduğunu söyleyen Bauman `a göre Panoptikon ${ }^{7}$, gözetim modellerinden sadece biridir. İktidarın artık elektronik teknolojiler vasıtasıyla ifade bulduğu günümüzdeki değişken ve mobil örgütlenmeler, duvarları ve pencereleri (sanal "güvenlik duvarları" ve "pencereler" hariç) büyük ölçüde gereksiz kilıyor. Bu da farklı yüzlere sahip birçok kontrol türünün ortaya çıkmasına olanak tanıyor. Bu kontrol türleri açık bir hapis bağlantısı barındırmamakla kalmaz, aynı zamanda eğlence ve tüketimde görülen esneklik ve eğlendiricilik özelliklerine de sahiptir. Artık güvenlik geleceğe dönük bir projeye dönüşmüş ve gelecekte olan şeyleri dijital teknikler ve istatistiksel akıl yürütme sayesinde denetlemeye çalışarak gözetim yoluyla işlemektedir (Bauman ve Lyon, 2013, s.12-13).

Yeni panoptik yapı Bentham `n modelinden daha karmaşıktır ve üretimden tüketime tüm toplumsal pratikleri belirleyen bir güçtür. Tüketim toplumunun bu bağlamda gözetim toplumuyla aynı anlama geldiği de öne sürülebilir. Kapitalist tekeller tüketim toplumunu tüm toplumları gözetim altında tutarak, disipline ederek, kapitalist ideolojiye uygun bir rasyonalite ile biçimlendirerek yeniden-üretmeye çalışmaktadır. Toplumsal ilişkilerin çözümlenmesi için panoptik yapının eleştirel bir biçimde ele alınması gerekir; "enformasyon teknolojileri toplumsal alanın iktidar ilişkilerini yansitmakta ve yeniden üretmektedir (Çoban, 2009).

Kozinets`e göre, kapitalist şirketlerin tüketiciler olarak gördüğü bu

\footnotetext{
${ }^{7}$ Panoptikon, Jeremy Bentham ile gündeme gelmiş ve projenin büyük bir bölümü ona ait olsa da, esas olarak kardeşi Samuel Bentham'ın fikridir. 1789 yılında Samuel Bentham tarafından tasarlanan panoptikon, merkezi denetim ilkesine dayanarak, daha çok işçinin gözetim altında tutulmasını sağlayan bir yapı olarak düşünülmüştür. Jeremy Bentham, 1786'da Rusya'ya abisini ziyarete gittiğinde bu projeden etkilenerek, bu mimarinin gözetimevi olmasının ötesinde hapishane gibi çok sayıda insanı gözetim altında tutacak yapılara uygulabileceğine karar vermiş ve bunun üzerine tasarladığı bu yapıyı 21 mektuptan oluşan "Panoptikon Mektupları"nda dile getirerek İngiliz hükümetine göndermiştir. Bu konuda detaylı bilgi için bakınız: Barış Çoban ve Zeynep Özarslan (Yay. Haz.) (2008). Panoptikon: Gözün İktidarı, İstanbul: Su Yayınları. Akt. Türkiye`de Dijital Gözetim, s.26
} 
özneler tüketmek için sürekli olarak gözetlemektedir, sürekli olarak tüketme arzusu ile hareket eden öznelerin varoluşu da bu arzu etrafında örgütlenmektedir ve "imaj kültürü tüketicilerde sadece izleme değil aynı zamanda izlenme arzusu da yaratmaktadır" (Kozinets, 2004, s.660, akt. Çoban, 2009). Özneler artık gözetlemekten ve gözetlenmekten zevk alır hale gelmektedir. $\mathrm{Bu}$ gerçeklik ise kapitalist iktidarın panoptik sistem bağlamında toplumsal özgürlüklerin yok edilmesi pahasına tüm toplumsal alanlarda güçlenmesi anlamına gelmektedir; "panoptik bakış daimi ve süreğendir, alışveriş merkezinde, bankada, metroda hatta bazen banyoda olmak bilinmeyen izleyicilerin önünde olmaktır." G. Marx`a göre bu durum sonucunda büyük kurumların birey üzerindeki iktidarı artmaya başlar. Toplumsal yaşamda kapitalizmin etkisinin yoğunlaşması toplumsal yaşamın tüketim üzerine kurulu acımasız bir cehenneme dönüşmesini beraberinde getirmektedir. Tüm toplumsal ilişkiler parçalanmakta, tüketim üzerinden yeniden yapılandırılmaktadır (Marx, 1985, s.28, akt. Çoban, 2009).

Böylesine bir takip edilme, gözetlenme sistemi içinde, kişilerde birbirleriyle kurdukları ilişkiler de gözetleme ve gözetlenme üzerine dayanır. Daha özgür olduğunu düşünen birey, aslında daha çok kontrol ediliyor, denetleniyor ve yönlendiriliyordur. Burada gözetleme ve gözetlenme üzerine kurulu bir iletişim algısından hareketle önerdiğim "gözetişim" kavramını tartışmak istiyorum. Dolayısıyla yeni medya alanları içinde "çoğullaştığımız (çoklaştığımız) bir simülasyon içinde aslında aynılaştık mı? Daha mı özgürleştik ya da daha mı çok denetleniyoruz? Gözetliyor muyuz ya da gözetleniyor muyuz? Görebiliyor muyuz?... Sadece görmek, gözetlemek ve gözetlenmek üzerine kurulu yaşamlar, bize yeni bir toplum biçimini vadetmektedir: Gözetişim toplumu!"

"Gözetişim" ${ }^{8 "}$ kavramından hareketle, herkesin birbirini görmek için yarıştığı ama görmezden geldiği; herkesin bir arada olduğu ama hiç kimsenin birbirini görmediği; herkesin gözetlediği ve gözetlendiği; hiç kimsenin görünür olmadığı ama herkesin görünür olduğu bir toplum tahayyül edilebilir mi? İçinden çıkılamaz bir paradoksa sahip olan böyle bir soruyu yanıtlamak elbette oldukça güçtür. Fakat elde edilen verilerden hareketle belki bir durum tasviri ve beraberinde ufak bir değerlendirme yapılarak, bu cevaba olasılıklı bazı cevaplar verilebilir. Sadece görünür

\footnotetext{
${ }^{8}$ Gözetişim kavramı Gözetleme ve İletişim kavramlarını birleştirerek ortaya atılmış ve ilk defa burada kullanılan bir kavramdır. Bu kavram iletişim kurmak amacıyla kullanılan ama iletişimi gözetleme ve gözetlenme üzerinden sürdürülen yeni medya alanlarında gerçekleşen bir iletişim biçimi anlamında kullanılmıştır. Sosyal bilimler alanında bu kavram ne kadar kabul görür bilinmez ama Facebook, Twitter, Instagram, Foursquare gibi sosyal paylaşım alanlarında gerçekleşen bir iletişim biçimi olarak düşünülebilir.
} 
olmak üzerinden kurulan bir iletişim biçimi. Bu iletişim biçimi tam da üzerinde tartıştığımız yeni iletişim teknolojileri ve sosyal medya üzerinden gözetleyerek, gözetlenerek, takip ederek, takip edilerek sürdürülmektedir.

Değişen iletişim teknolojileri toplum yapısını değiştirmekte değişen yapısı ise toplumsal talepleri ve beklentileri de belirlemektedir. Gittikçe kapatıldığımız ve kapandığımız yeni dünya içinde dijital olarak sürdürdüğümüz yaşamlar, ilişkiler, tepkiler, beklentiler, beğeniler gittikçe benzeşmekte ve aynılaşmaktadır. En temel fizyolojik ve biyolojik farklılıklarımızın bile silindiği alanlarda kapandığımız (kapatıldığımız) alanlarda ya gözetliyoruz ya da gözetleniyoruz. Büyük ölçüde farkındalığın olduğu her iki durumda da benzerimizle aynı safta yer almayı tercih ediyoruz. Yani gittikçe daha fazla "özne"ler haline geliyoruz ama tüm öznelliklerimizi, bizi biz yapan en ayırt edici özelliklerimizi yitiriyoruz. Benzer ve farklı olanlarımızla olan sınır çizgilerini iyice belirginleştirip kendi kamp alanlarımızı yaratıyor. Bu kamp alanları ise yeni medya alanında ya da dijital dünya da çevrimiçi ya da çevrimdışı olmayı ifade ediyor. Bauman `a göre bu "çevrimiçi" ve "çevrimdışı" hayat tanımlaması ya da nitelemesi tam da bu içerme ve dışarda bırakma durumunu ifade ediyor:

Tüketim toplumuna ve fark edilme dürtüsüne ayak uyduranlar "şansh" çoğunluk içinde "çevrimiçi" bir yaşam sürüyor; kitleyle yakınlık kurmanın yolu da buradan geçiyor ve kişi "ağ"a dahil oluyor. İçine girilen ă̆, belli bir noktadan sonra her alana nüfuz ediyor; akışkan modern dünyanın insan ya da çalışanları kişisel panoptikonların kendi bedenleri üzerinde büyütmek ve taşımak zorunda kalıyor. Kişi, tüketici pazarının cazibesine kapılarak "kendisinin bekçisi olmak üzere eğitiliyor. Ve böylece gözetim toplumunun iki farklı cephesi/kampı karşımıza çıkıyor: Cephede hapsetmek (çitin içine almak) ve cephenin dışında/dışarıda bırakmak (çitin dışına itmek) (Bauman ve Lyon, 2013, s.69).

Böylece birey istediğini içeri alıyor ve istemediğini kendisi için tehdit unsuru olanı dışarda bırakıyor. Böylece karşımıza gittikçe parçalı bir toplum yapısı çıkıyor. Ve dijital alanlarda gerçekleşen bu parçalı yapı, gittikçe gerçek toplumsal alanın yerini almaya başlıyor. Bauman'a göre "sosyal medya toplumsal parçalanmanın bir sonucu değil, aynı zamanda toplumsal parçalanma da muhakkak ki sosyal medyanın bir sonucudur." (Bauman ve Lyon, 2013, s.14) Dolayısıyla Bauman, toplumsal alandaki kopuşları ve kendi alanlarını oluşturarak kapanmayı sosyal medyanın gittikçe güçlenmesinin bir sonucu olarak görüyor. Aslında bu durum sadece sosyal medya değil, internet teknolojisinin bu kadar hızlı gelişip yaygınlaşmasının da bir sonucu olarak düşünülebilir. Çünkü her işimizi internet üzerinden hallediyor olmak, kaçınılmaz olarak bizleri internet başına hapsetmekte, dışarısı ile 
olan ilişkimizi (sokakla olan ilişkimizi) yeniden tanımlamakta ve anlamlandırmaktadır. Toplum içindeki bireyler artık internet çağında toplumun varolan ama görünmeyen varlıkları olarak karşımıza çıkıyor. Yani toplumun bireyleri, internet toplumunda hayaletler olarak karşımızdadır.

Toplumsal bedenin görünmeden gören iktidar tarafından disipline edilmesi, süreğen bir gözetim sistemi ile gerçekleştirilir (Çoban, 2009). Facebook, twitter gibi sosyal medya araçları bireye sağladığı "görünmeden görme" imkanıla yeni iktidar alanları yaratmakta ve herkesin birbirini gözetlediği ama herkesin bunu bilip de bilmezlikten geldiği yeni durumlar yaratmaktadır. Bu "görünmeden görme" olanağıyla yeni iktidar algıları yaratmakta ve herkes kendini güce sahip ve gücü kontrol eden yeni iktidarlar yaratmaktadır. Bu durum bize her ne kadar görünmeyen ama var olduğu bilinen 18. yüzyıl Avrupa kentlerinin flanörlerini hatırlatsa da, burada birey gördüğünü ama görünmediğini zannetmektedir. Herkes birbirini gözetlemekte ama büyük güç odakları (üretici güçler, siyasal güçler) herkesi gözetlemektedir.

Baudelaire ve Benjamin in modernliğin sembolü olarak gördükleri flanör, kenti seyreden, sokaklarında sessizce dolaşan, görünmeyen ama gördüklerini de zaman zaman paylaşan bir kişi olsa da, sosyal medyanın dijital flanörü de, internetin sokaklarında gizlice dolaşan, görünmeden insanları seyreden ve gördüklerini paylaşan bir internet aktörü olarak karşımızdadır. 18. yüzyılın flanörünün amacı "yakalanmadan seyretmektir" yani görünmeden görmektir. Kimliğini özellikle saklamak gibi bir derdi olmasa da, flanör tanınmadan gezmeyi tercih ederdi. Zygmund Bauman'ın dediği gibi, "flanörün ustası olduğu sanat, baktığını fark ettirmeden görmekti". Flanör asosyal değildi, yaşamak için kalabalıklara ihtiyacı vardı; ama kalabalıklara kaynamaz, yalnızlığının üzerine titrerdi. Ve dünya kadar zamanı vardı: Kaplumbağalarını yürüyüşe çıkaran flanörler olduğu söylenirdi (Mozorov, 2012). Fakat dijital flanör9', gözlemek ve gözlenmek üzerine bir alanda var olmaktadır. Ve bu görünürlüğünü nitel olarak sergilemek ister: Kaç arkadaşı ve takipcisi var?, Kaç beğeni almış?, Ne kadar yorum yapılmış?, Kaç bilgi aktarımı var? vs gibi.

\section{Sonuç: Modernlik Sarkacı}

Yeni iletişim teknolojileri makine üretir ve bireyler, bir tüketim

\footnotetext{
${ }^{9}$ Morozov ilgili makalesinde "siberflanör" kavramından bahseder ve facebook gibi sosyal medya araçlarının bu kavramı ortadan kaldırdığını, çünkü bu sosyal medya araçlarının hem görmeye hem de görünmeye dayalı bir anlayışa sahip olduğunu söylemektedir. Bu nedenle burada "dijital flanör" kavramını kullanmak istedim. Sosyal medyanın flanörünün ustalı̆̆ hem gözetlemeye hem de gözetlenmeye dayanırken, bunu sayısal olarak da ölçme derdindedir.
} 
döngüsü içinde sürekli olarak bu makinelere sahip olmaya çabalar. Böylece makinenin tahakkümü (cep telefonları, internet, sosyal medya vs) altına giren bireyler, makinelere bağıml ve onların kontrol ve denetiminde toplumsal gerçekliğin dışında sanal alanlarda varlıklarını yeniden tanımlayıp, sürdürmeye başlarlar. Bu yeni yaşam alanları olarak yeni medya alanları, yeni toplumsallıklar ve bu toplumsallıklar içinde yeni ilişki ve iletişim biçimleri ve yeni kimlikler yaratır. Bunlarla birlikte kendi kültürünü, sosyalleşme alanlarını/mekanlarını ve yaşam biçimlerini de ortaya koymaya başlar. Tüm bu alanlar gerçek toplumsal alanlardan farklı olarak sümülasyonlar yaratmaktadır. Burada gerçeklikle hayalin iç içe geçtiği ve bunları birbirinden ayıramadığımız algılar ve yeni gerçeklikler, simülarklar sunulur. Tam da Deleuze ve Guattari nin de ifade ettiği gibi kapitazlimin yarattı̆̆1 dünya hayalle gerçeğin iç içe geçtiği ve bunu bireyin ayırt edemediği bir yaşam sunar. Yani kapitalizm şizofrenler yaratır.

Bir diğer önemli nokta ise sayısal olarak algılandığımız ve her şeyi sayısal olarak algıladığımız, değerlendirdiğimiz bir dijital bir dönemdeyiz. $\mathrm{Bu}$ durumun en doğrudan gözlemlendiği alan ise sosyal medya alanlarıdır. Her şeyi sosyal medya üzerinden tartışıyoruz, konuşuyoruz: her bir beğeni, etiketleme, taşıma bizi bu dünyadaki varoluşumuzu gerçekleştiriyor. Sayılarla ifade ediliyoruz: arkadaş sayısı, takipçi sayısı, beğeni sayısı, yorum sayısı, yorumun ve paylaşımın taşınma sayısı...

Gittikçe kapatıldığımız ve kapandığımız yeni dünya içinde dijital olarak sürdürdüğümüz yaşamlar, ilişkiler, tepkiler, beklentiler, beğeniler gittikçe benzeşmekte ve aynılaşmaktadır. En temel fizyolojik ve biyolojik farklılıklarımızın bile silindiği alanlarda kapandığımız (kapatıldığımız) alanlarda ya gözetliyoruz ya da gözetleniyoruz.

Bireysel farklılıkların kaybolduğu bu yeni toplumsal alanlarda belirginleşen gözetim, zaman ve mekan mefhumunu aşarak akışkan bir biçimde zihinlere ve yaşamlara sızarak herkesi birbirine benzetmektedir. Yeni medya ve bu akışkan ilişkiler, karşılıklı olarak birbirlerini var etmekte ve sürekli olarak dönüştürmektedir. Yeni medya biryandan toplumsal ilişkileri parçalamakta ama bir yandan yeni gruplar (kamplar) oluşturarak mahremiyetin kaybolduğu yeni yaşam alanları yaratmaktadır. Büyük ölçüde farkındalığın olduğu her iki durumda da benzerimizle aynı safta yer almayı tercih ediyoruz. Yani gittikçe daha fazla "özne"ler haline geliyoruz ama tüm öznelliklerimizi yitiriyoruz. 


\section{Kaynakça}

2014 Global Digital Statistics, http://wearesocial.net (25.07.2014)

ÇOBAN, B. ve Özarslan, Z. (ed.) (2008). Panoptikon: Gözün İktidarl, İstanbul: Su Yayınları.

BAUMAN ve Lyon (2013), Akışkan Gözetim.

BAUMAN, Zygmunt (2006) Küreselleşme, çev. Abdullah Yılmaz, Ayrıntı Yayınları:İstanbul

BERMAN, Marshall (2004), Katı olan Herşey Buharlaşıyor, İletişim Yayınları:İstanbul

CAMPBELL, J.E., Carlson, M. (2002). “Panopticon.com: Online Surveillance and the Commodification of Privacy". Journal of Broadcasting \& Electronic Media. December. p.586-606

CASTELLS, Manuel (2005), "Enformasyonculuk ve Network Toplumu", Hacker Etiği: İş Hayatına Yıkıcı Bir Yaklaşım, Pekka Himanen, çev. S,ebnem Kaptan, Ayrıntı Yayınları: İstanbul, s. 123-133

CASTELLS, Manuel (2008), Enformasyon Çağı: Ekonomi, Toplum ve Kültür II - “Kimliğin Gücü”, Bilgi Üniversitesi Yayınları:İstanbul, s.4-5

ÇOBAN, Barış (2009), "Yeni Panoptikon, Gözün İktidarı ve Facebook", Yeditepe İletişim Fakültesi Dergisi, sayı:10

GIDDENS Anthony (2008), Ulus Devlet ve Şiddet, Kalkedon Yayınları:İstanbul

GÜLŞAH Başlar, "Yeni Medyanın Gelişimi ve Dijitalleşen Kapitalizm", Marmara Üniversitesi, Radyo Televizyon ve Sinema Bölümü, Araştırma Görevlisi

http://blog.artuc.net/dijital-yasamlar/ (03.04.2014)

KOZINETS, R. V., Sherry, J. F., Jr., Storm, D., Duhachek, A., Nuttavuthisit, K., \& Deberry-Spence, B. (2004, December). "Ludic Agency and Retail Spectacle". Journal of Consumer Research, 31, p.658-672.

MARX, G. (1985), "I'll Be Watching You: Reflections on the New Surveillance", Dissent (USA),Winter 1985:p.26-34.

MAYFIELD, A., What's Social Media?

MOROZOV, Evgeny (2012), Sosyalliğin ve Umumiyetin Zorbahı̆g: Siberfalanörün Ölümü", Çeviri: Elçin Gen, http://www.eskop.com/skopbulten/sosyalligin-ve-umumiyetin-zorbaligi-siberflanorunolumu/568, (23.04.2014)

ÖZKAZANÇ Alev (2007). “Biyo-politik Çağda Suç ve Cezalandırma: Denetim Toplumunda Neo-liberal Yönetimsellik", Toplum ve Bilim, 108 , s.15-51.

RYAN, J. A History of The Internet and The Digital Future, Rreaktion Books: 
London, (2010)

TOKTAŞ, Binark, Dikmen, Fidaner, Kuzeci, Özaygen (2012), Türkiye`de Dijital Gözetim: T.C. Kimlik Numarasından E-Kimlik Kartlarına Yurttaşın Sayısal Bedenlenişi, Alternatif Bilişim Derneği Yay.: Ankara, s.17

TOPRAK, Binark, Yıldırım, Aygül, Börekçi, Comu (2009). Toplumsal Paylaşım A ̆̆ı Facebook: Görülüyorum Öyleyse Varım!, Kalkedon Yayınları: İstanbul

ZAMYATIN, Yevgeni (2010), Biz, Ayrıntı Yayınları: İstanbul / (2013), Versus Yayınları: İstanbul 